A Tribute to Romualdo Abulad, the Filipino Kantian

\title{
Introduction to the Special Tribute Section: Abulad, Philosophy, and Intellectual Generosity
}

Paolo A. Bolaños

$\mathrm{I}$ n this special section of the December 2019 issue of Kritike: An Online Journal of Philosophy, we pay homage to the intellectual legacy of one of the original members of the International Advisory Board of the journal, Romualdo Estacio Abulad (1947-2019). Born 21 September 1947 in Lucban, Quezon, he graduated Salutatorian from Lucban Academy in 1964. After high school, he attended the University of Santo Tomas in Manila and obtained a Bachelor's degree in philosophy in 1969. From 1969 to 1978 - while teaching philosophy in the University of Santo Tomas, then in De La Salle University he studied for his Master's and Doctoral degrees in philosophy at the Ateneo de Manila University and the University of Santo Tomas, respectively. He specialized in the philosophy of Immanuel Kant and, for his Doctoral work, he defended a dissertation that compared the thoughts of Kant and Shankara. ${ }^{1}$ After being granted a fellowship from the Alexander von Humboldt Stiftung, he spent a couple of years (1979-1981) at the University of Hamburg, Germany, to deepen his grasp of the philosophy of Kant, resulting in the work, "Criticism and Eternal Peace: Kant's Critique of Pure Reason as the Method of Scientific Metaphysics." 2 In addition to his graduate research in philosophy, he wrote a thesis for a Master's in Theology degree at the Divine Word Seminary in Tagaytay City titled, "Toward a Reconstruction of Christology in the Context of Postmodernity."3

Abulad started a career in teaching immediately after finishing college in 1969 at the University of Santo Tomas, where he would teach until 1972. With the help of his mentor, Emerita Quito, he was able to secure a

\footnotetext{
1 See Romualdo E. Abulad, "The Status of Metaphysics in Kant's Critique of Pure Reason" (Master's Thesis, Ateneo de Manila University, 1975) and "Links Between East and West in the Philosophies of Shankara and Kant" (Ph.D. Dissertation, University of Santo Tomas, 1978).

${ }^{2}$ See Romualdo E. Abulad, “Criticism and Eternal Peace: Kant's Critique of Pure Reason as the Method of Scientific Metaphysics" (Postdoctoral Research, University of Hamburg, 1980).

${ }^{3}$ See Romualdo E. Abulad, "Toward a Reconstruction of Christology in the Context of Postmodernity" (Master's Thesis, Divine Word Seminary, 2003).
}

(c) 2019 Paolo A. Bolaños

https://www.kritike.org/journal/issue 25/bolanos december2019.pdf

ISSN 1908-7330

$(\mathrm{Cc}) \overline{\text { BY-NC-ND }}$ 


\section{ABULAD, PHILOSOPHY, AND INTELLECTUAL GENEROSITY}

teaching post at De La Salle University and would spend two very productive decades there from 1972 to 1993. Along with Quito, Abulad was instrumental in developing the culture of research at the Department of Philosophy of De La Salle. In a 2016 interview, Abulad relates that, apart from Quito's prodding, he decided to transfer to De La Salle because the intellectual climate there in the 1970s was more conducive to philosophical research than in Santo Tomas, as the former institution was more progressive and "revolutionary" while the latter was, during that time, still conservatively Thomistic in orientation. ${ }^{4} \mathrm{He}$ would eventually replace Quito as the head of the Department. At the age of 46, Abulad entered the Societas Verbi Divini (SVD) and would spend six years of religious formation. From 1999 to 2013, the University of San Carlos in Cebu City became his home for a decade and a half, where he first served as the Vice-President for Academic Affairs and then the Chair of the Department of Philosophy (which later on became Department of Philosophy and Religious Studies). During that period, he would occasionally be invited to teach philosophy courses in the University of Santo Tomas. After heading the Department of Philosophy of San Carlos for four years, Abulad returned to Manila in 2013, eventually finding his academic home in his alma mater, the University of Santo Tomas, where he became a member of the Department of Philosophy as a Professorial Lecturer. At the same time, he was a formator and Dean of Studies at the Christ the King Mission Seminary in Quezon City. On 17 December 2019, news of Abulad's sudden death overwhelmed the Filipino philosophical community. He was 72 years old.

Abulad's intellectual productivity spanned five decades (1970-2019). The most productive decades are 1981-1990 and 2001-2010, while the least productive was 1991-2000, the period when he entered the religious vocation. While Abulad did not leave us, strictly speaking, with a magnum opus, his contribution to the literature of Filipino philosophy is, I would argue, one of the most impressive and extensive. He belongs to the "first wave" of Filipino academics who brought home new philosophical knowledge from their studies overseas. ${ }^{5}$ And, like his mentor Quito, Abulad could be credited for ushering in the local appropriation of continental philosophy, especially in the University of Santo Tomas, De La Salle University, University of San Carlos, and Christ the King Mission Seminary, among many other schools. The absence of a magnum opus, however, does not necessarily mean that it would be impossible to reconstruct what Abulad had contributed to the

\footnotetext{
${ }^{4}$ Romuald E. Abulad and Emmanuel C. de Leon, "An Interview with Romualdo Abulad, SVD," Kritike: An Online Journal of Philosophy, 10:1 (June 2016), 12.

${ }_{5}$ Alfredo P. Co, "In the Beginning ... A Petit Personal Historical Narrative of the Beginning of Philosophy in the Philippines," in Across the Philosophical Silkroad: A Festschrift in Honor of Alfredo P. Co, Vol. VI (Manila: University of Santo Tomas Publishing House, 2009), 36.

(C) 2019 Paolo A. Bolaños

https://www.kritike.org/journal/issue 25/bolanos december2019.pdf

ISSN 1908-7330
}

(c) $)$ BY-NC-ND 
intellectual culture of the Philippines. Gleaned from the numerous essays that he has written in the span of five decades, one notices at least three dominant recurring preoccupations in his writings: German philosophy (in the specific order, Kant studies, phenomenology, and hermeneutics), postmodernism, and Filipino philosophy.

In what follows I will present a periodization of Abulad's productive career as a Filipino philosopher. It is worthwhile to briefly examine each period in order to demonstrate how Abulad's philosophical mind evolved. However, while I try to be accurate, I do not intend the periodization below to be exhaustive. By no means is this the last essay on Abulad, it is now time to assess his philosophical contribution critically, that is, we must do Filipino philosophy.

The 1970-1980 period marks the beginning years of Abulad's intellectual legacy. His writings during this period are his first attempts, as a young scholar, to present to the local philosophical community his in-depth studies of Kant-focusing on Kantian metaphysics, epistemology, critique, ethics, science, and comparative studies between Kant and Eastern philosophy. ${ }^{6}$ During this period, Abulad also attempted to lay on the table his initial thoughts on the relationship between philosophy and being Filipino. ${ }^{7}$

In 1981, Abulad returned from his studies in Europe and embarked on one of the most philosophically productive decades of his career, 19811990. This period is characterized by Abulad's preoccupation with German philosophy and Filipino philosophy. He continued, from the previous decade, his exposition of Kant's philosophy, ${ }^{8}$ but this time he contextualized Kant with Filipino readers in mind; more specifically, he did not only expose Kant, but used Kantian ideas to make sense of Filipino philosophy. ${ }^{9}$

${ }^{6}$ See Abulad's essays in the journal Sophia, published by the Department of Philosophy of De La Salle University: "Kant's Critique of Pure Reason: A Science, a Discipline and a Consciousness," 2:1 (September 1972), 29-45; "Projective Morality: An Ethics for a New Society," 2:2 (November 1972), 94-99; "Rousseau and Kant," 2:3 (January 1973), 130-133; "Kant's Metaphysics" 4 (April 1974), "Toward a Philosophy of Science," 3:3 (January 1974); "The Materialist Prospect," 4:3 (February-May 1975), “Can Science Save the World?," 5:3 (FebruaryMay 1976). Also see the outcomes of his graduate and post-doctoral researches: "The Status of Metaphysics in Kant's Critique of Pure Reason," "Links Between East and West in the Philosophies of Shankara and Kant," and "Criticism and Eternal Peace: Kant's Critique of Pure Reason as the Method of Scientific Metaphysics."

7 See Romualdo E. Abulad, “Pilipino sa Pilosopiya," Dialogue, 12:1 (August 1976), 159168.

8 See the following essays in Sophia: "Three Problems in Kant's Philosophy," 11:3 (January-April 1982), 158-167; "Shankara and Kant: A Comparison," 14:2 (September-December 1984), 73-97; "Kant's View of Science," 17:1 (August 1987), 8-18; “Kant's Philosophy of Man," 20:1 (May-August 1990), 32-46.

${ }^{9}$ See the following essays in Sophia: "Kant and the Filipino Quest for a Philosophy," 11:1 (May-August 1981), 34-49; "Rationale for a Filipino Philosophy," 12:1 (May-August 1982), 1-16; "Kant and the Task of Contemporary Filipino Philosophy," 16:1 (May-August 1986), 45-68; "Kant

(c) 2019 Paolo A. Bolaños

https://www.kritike.org/journal/issue 25/bolanos december2019.pdf

ISSN 1908-7330

(cc) BY-NC-ND 


\section{ABULAD, PHILOSOPHY, AND INTELLECTUAL GENEROSITY}

Moreover, a more engaged grappling with the question of whether or not there is such a thing as "Filipino philosophy" is more pronounced in this period, as Abulad also went beyond Kant and presented his peculiar schematization-for instance in the 1984 essay "Options for a Filipino Philosophy" - of what he thought was the possibility of indigenous thought and how it interfaced with Western philosophy. ${ }^{10}$ At the background of these musings, Abulad underscores the revolutionary character of Filipino thought and culture. ${ }^{11}$ This productive decade also features essays on other continental thinkers, namely, Martin Heidegger and Georg Simmel. ${ }^{12}$

The period 1991-2000, while not the most productive decade in terms of publication, marks an important turning point in the academic career of Abulad for two related reasons. First, because it was during this period when he joined religious life as an SVD brother and, somewhat, turned his attention towards theological/religious studies. ${ }^{13}$ Second, and more interestingly, because this was the decade when he discovered the up and coming philosophical trend during that time, "postmodernism," of which he became a consistent mouthpiece in the ensuing years. ${ }^{14}$ It could be argued that, apart from being recognized as the premier Kantian scholar in the country, on account of his numerous writings on Kant, Abulad earned the reputation as the philosopher of postmodernism after the publication of the essay "What is Postmodernism?" which proved influential among the younger generation of aspiring Filipino philosophers. ${ }^{15}$ While he was not the first Filipino author to have spoken or written about postmodernism, he was certainly the most

for Filipinos," 16:2 (September-December 1986), 37-56. Also see "Si Kant at ang Pilosopiya sa Pilipinas," Malay, 1:1 (September 1981), 57-68.

${ }^{10}$ See Abulad's essays in volumes 1, 5, and 7, respectively, of the journal Karunungan, the official journal of the Philippine Academy of Philosophical Research (PAPR): “Options for a Filipino Philosophy" (1984), 17-30; “Contemporary Filipino Philosophy” (1988), 1-13; “Filipino Philosophy in Dialogue with Plato" (1990), 1-13.

11 See Romualdo E. Abulad, "Ang Diwa at Kaisipan ng Pilipino sa Kasaysayan ng Himagsikan," Malay, 5:5 (June-December 1986), 37-48 and "Revolution Through Values," Sinag, 1:1 (October 1989), 25-37. Moreover, a related piece is on the relationship between philosophy and values education: "The Philosophical Bases of Values Education," The DLSU Graduate Journal, 12:2 (1987), 145-158.

${ }^{12}$ For instance, Romualdo E. Abulad, "Heidegger and the Pursuit of Being," Sophia, 19711981: The Best of A Decade (1981), 39-56; “Martin Heidegger: Mula Penomenolohiya Hanggang Eksistensiyalismo Hanggang Hermeneutika," Malay, 8:1-2 (1989-1990), 47-64; “Ang Pilosopiya ng Salapi ni Georg Simmel," Karunungan, 6 (1989), 1-15.

${ }^{13}$ For instance, see Romualdo E. Abulad, "The Mystical Philosophy of St. John of the Cross," Karunungan, 9 (1992), 40-58.

14 See Romualdo E. Abulad, "Origen's Contra Celsum: A Touch of Postmodernism," Diwa: Studies in Philosophy and Theology, 22:1 (May 1997), 26-40; "Kant and Postmodernism," PHAVISMINDA Journal, 2 (May 1998), 32-51; "Facing the Moral Challenge of the Post-Modern Times," Karunungan, 16 (1999), 1-3.

${ }^{15}$ See Romualdo E. Abulad, “What is Postmodernism?," Karunungan, 17 (2000), 34-54.

(C) 2019 Paolo A. Bolaños

https://www.kritike.org/journal/issue 25/bolanos december2019.pdf

ISSN 1908-7330

(c) ) BY-NC-ND 
fearless and vocal advocate of his own brand of postmodernism, earning him not only the praise of followers, but also the ire of critics.

The most productive decade of Abulad was the 2001-2010 period, his years at the University of San Carlos. It is perhaps appropriate to refer to this period as the beginning of the philosophically mature Abulad, wherein his writings on postmodernism are the most pronounced. By this time, what he meant by "postmodernism," albeit idiosyncratic, was already clear in his mind. This allowed him to discuss the topic with ease and flexibility. This means that the theme of postmodernism became relevant to whatever topic he was tackling: God, religion, ethics, eastern philosophy, technology, scholasticism, politics, dialogue, Kant, and Filipino philosophy. ${ }^{16}$ Abulad, of course, did not abandon his beloved Immanuel Kant-if in the essay of the previous decade, "What is Postmodernism?," he argued that Nietzsche is the father of postmodernism, in 2005, in his essay "Immanuel Kant as a Pioneer of Postmodernity," he started claiming that it was actually Kant who ushered in the postmodern attitude, a claim he would sustain for the rest of his productive years. ${ }^{17}$ In 2003 and 2004, respectively, Abulad came full circle with his studies on postmodernism with the completion of "Toward a Reconstruction of Christology in the Context of Postmodernity" and the publication of Two Filipino Thomasian Philosophers on Postmodernism, a collaborative work which he co-authored with his long-time friend, the sinologist Alfredo Co. ${ }^{18}$ I must also add that during this period, while there is no systematic political philosophy that Abulad developed, his philosophical stance on social and political matters became more articulated. ${ }^{19}$

16 See Abulad's articles in Karunungan: "God and Postmodernity," 19 (2002), 5-13; "Postmodern Critique and the Ethics of Postmodernism," 19 (2002), 65-80; "The Significance of Kong $\mathrm{Zi}$ in the Age of Postmodernism," 20 (2003), 1-21; "Fundamental Assumptions of Postmodernity," 21 (2004), 83-120; "The Role of Philosophy in the Technological Age," 21 (2004), 170-184; “St. Thomas Aquinas and Postmodernism," 22 (2005), 53-61; “Prophetic Dialogue Across Civilizations," 25 (September 2008), 23-26. See also his articles in the USC Graduate Journal: "Filipino Philosophy in the Turbulent Period of Postmodern Transition," 22:1 (October 2005), 148-165 and "Paradigm Shifts and Some Postmodern Prospects: Toward a Postmodern Filipino Philosophy," 26:2 (October 2009), 167-176. Moreover, see "The Future of Ethics: A Postmodern View," Diwa: Studies in Philosophy and Theology, 27:1 (May 2002), 14-31; "The Meaning of Postmodernism," Talad, 4:2 (July 2004), 138-149; "Philosophy and Politics: Do They Mix?," PHAVISMINDA Journal, 8 May 2009), 1-18.

17 See Romualdo E. Abulad, "Immanuel Kant as a Pioneer of Postmodernity," The Thomasian Philosopher, 26 (2005), 120-128.

${ }^{18}$ See Romualdo E. Abulad and Alfredo P. Co, Two Filipino Thomasian Philosophers on Postmodernism, ed. by Romualdo E. Abulad (Manila: University of Santo Tomas Publishing House, 2004).

${ }^{19}$ For instance, in the following articles published in Volume 18 (2001) of the Karunugan: "A Philosopher's View from EDSA," 11-14 and "Post-Machiavelli," 91-100. See also, "Philosophy, Life, History," FEU Arts and Sciences Review, 4 (2001), 20-35.

(c) 2019 Paolo A. Bolaños

https://www.kritike.org/journal/issue 25/bolanos december2019.pdf

ISSN 1908-7330

(cc) BY-NC-ND 


\section{ABULAD, PHILOSOPHY, AND INTELLECTUAL GENEROSITY}

Unfortunately, 2011-2019 would be his last prolific decade. In this mature period, Abulad seemed to have focused more on ethical considerations involving politics, society, and culture-notwithstanding the fact that these discussions are, still, informed by Kant, postmodernism, and now, perhaps, a more assured notion of Filipino philosophy. In terms of politics, for instance, Abulad published papers that deal with issues, such as, the relationship between governance and glocalization, the relationship between martial law and religion, ${ }^{20}$ and, more recently, controversial (and perhaps for some, fallaciously irresponsible) ${ }^{21}$ pieces that appear to be polemics in support of the Duterte administration. ${ }^{22}$ Meanwhile, his most recent essays on society and culture tackle the question of the relevance of philosophy (or sometimes referring to it as critical thinking) in nation building or cultural formation, ${ }^{23}$ as well as the questions on the contemporary roles of atheism, freedom, and responsibility. ${ }^{24}$

While not impossible, it is not easy to reconstruct Abulad's intellectual contribution. Unlike his philosophical hero Kant, Abulad was simply not a system builder, despite the scholarly rigor that his essays demonstrate. It is, thus, ill-advised to look for something that does not exist. Abulad offers neither a metaphysics nor an epistemology; neither a moral philosophy nor a philosophical anthropology. Nevertheless, and this is perhaps the genius of his work, in almost every essay he wrote, he narrates a story of metaphysics, epistemology, moral philosophy, and philosophical

${ }^{20}$ See Romuald E. Abulad, "Ethics and Governance in the Postmodern Glocalized Society," USC Graduate Journal, 28:2 (March 2012), 161-183 and "Martial Law and Religion," Scientia, 6:2 (December 2017), 45-59, <http://scientia-sanbeda.org/wp-content/uploads/2017/12/3abulad.pdf>.

${ }^{21}$ A case in point is the critical essay written by Abulad's confrere, Raymun J. Festin, where the latter criticizes the former for writing a titillating, yet philosophically fallacious, defense of President Rodrigo Duterte. See Raymun J. Festin, "Duterte, Kant, and Philosophy," PHAVISMINDA Journal, 16-17 (May 2018), 16-96. Festin is referring to Abulad's essay, "Why President Duterte Could be Correct," in King's Clarion (Christ the King Seminary, Quezon City: June 2016-2017).

22 See, for instance, ibid. and Romualdo E. Abulad, "Ethics, Indigenous Ethics, and the Contemporary Challenge: Attempt at a Report on Ethics for the Filipino Today," Scientia, 8:1 (March 2019), 1-20, <http://scientia-sanbeda.org/wp-content/uploads/2019/03/1Abulad.pdf >.

${ }^{23}$ See Romualdo E. Abulad, "Doing Philosophy in the Philippines: Towards a More Responsive Philosophy for the 21 $1^{\text {st }}$ Century," Suri, 5:1 (2016), 1-20,

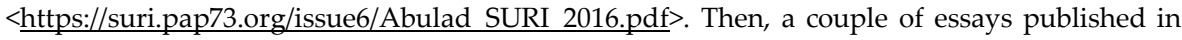
Scientia: "Confucianism and Filipino Culture," 5:2 (December 2016), 1-16, < http://scientiasanbeda.org/wp-content/uploads/2017/05/vol-5.2-r-abulad.pdf $>$ and "The Relevance of Critical thinking in Contemporary Philippine Society," 6:1 (June 2017), 34-66, < http://scientiasanbeda.org/wp-content/uploads/2017/06/2-R-E-Abulad.pdf>.

${ }^{24}$ See the following essays published in Diwa: Studies in Philosophy and Theology: "Atheism as a Prophetic Voice in the Era of Paradigm Shift," 38:2 (November 2013), 77-90 and "Freedom and Responsibility: The Millenials' Quest for and Integration of the Good," 43:1 (May 2019), 334.

(C) 2019 Paolo A. Bolaños

https://www.kritike.org/journal/issue 25/bolanos december2019.pdf

ISSN 1908-7330

(cc) BY-NC-ND 
anthropology. But by narrating a story, Abulad was most philosophical, as he demonstrated the dialectical, and hence deeply ethical, movement of thinking. His style of philosophizing is an example of what I would term as an "ethics of thinking" - a kind of thinking that is radical or raw, yet disciplined; committed, yet unprejudicial; critical, yet accommodating. The ethics of thinking, too, is a disposition, even a predisposition (Veranlagung), and Abulad personified this not only through his writing, but through the life he had chosen to live and the way he treated people around him.

A famous line from Susan Sontag, commenting on Theodor Adorno's oeuvre, is usually used as blurb for Adorno's books: "A volume of Adorno's essays is equivalent to a whole shelf of books on literature." I wish to borrow this line to describe the work of Abulad, but in a slightly modified form: "An essay of Abulad is equivalent to the whole history of philosophy." Yes, indeed, that is how he wrote his essays. In order to expound on a point, he had to take his listeners and readers with him in a journey back to the history of philosophy of his own peculiar telling, that is, his own philosophical Denkbild, often a fusion of horizons between the East and the West, but always Abulad's own constellation of concepts borrowed from the history of thought. One could observe that his narrative of the history of philosophy is idiosyncratic, yet pedagogically effective; selective, yet generous in thought. Kant is, of course, the starting point of Abulad's story, much like the pivot that holds a pendulum. From Kant, he tells a story of philosophy by swinging to the ancient- and medieval philosophers, then back to Kant so that he could continue the story of the modern- and contemporary philosophers. Despite his numerous essays, Abulad is just telling one story-a Bildungsroman of philosophy, wherein Kant, postmodernism, and Filipino thought are the main catalysts. Or, perhaps, also quite idiosyncratically, his writings are a Bildungsroman of the making of a Filipino philosopher called Abulad.

In this special tribute section, a couple of Abulad's penultimate writings are published here in Kritike for the very first time. As penultimate writings, they represent his mature insights on two topics he was famous for discussing: Filipino philosophy and postmodernism. The first essay, "Pilosopiyang Pinoy: Uso Pa Ba? (The Relevance of Filipino Philosophy in Social Renewal)," was written in 2010, hence, his last essay during the 20012010 period. Meanwhile, in 2017, he wrote "Filipino Postmodernity: Quo Vadis?," which now represents his last decade, 2011-2019. In order to allow Abulad to speak for himself, we preserved the original structures and tenses of the essays; we have tried our best to refrain from intervening too much by way of editorial reformatting. As necessary, however, we have corrected typographical errors and supplied a few missing footnotes. Judging from the titles of these essays, Abulad was tracing, as it were, the progress of the

(c) 2019 Paolo A. Bolaños

https://www.kritike.org/journal/issue 25/bolanos december2019.pdf

ISSN 1908-7330

(cc) BY-NC-ND 


\section{ABULAD, PHILOSOPHY, AND INTELLECTUAL GENEROSITY}

discourse on Filipino philosophy and, in a related way, postmodernity within a Filipino context.

Unlike many papers that merely chronicle the status of the written works of Filipino intellectuals, Abulad does something quite unprecedented in "Pilosopiyang Pinoy: Uso Pa Ba? (The Relevance of Filipino Philosophy in Social Renewal)." At least, it is unprecedented in that he does more than merely presenting a taxonomical description of the individual contributions of writers his contemporary, such as, Leonardo Mercado, Dionisio Miranda, Albert Alejo, Rolando Gripaldo, Florentino Timbreza, and Emerita Quito. Instead, Abulad demonstrates a kind of intellectual generosity in that he examined carefully, and generously, the respective takes of these authors on Filipino philosophy, even if he disagrees with them fundamentally. Through his generous reading, he does not only provide competent reconstructions of the respective positions of these authors, culled from their major works on Filipino philosophy and Filipino values, ${ }^{25}$ but, more importantly, Abulad points out the deficiencies of each author's claim. The works of Mercado, Miranda, Alejo, Gripaldo, and Timbreza, Abulad notes, are examples of the "anthropological approach" - an approach that mimics, as the name goes, the practice of anthropologists. What these quasi-anthropological studies have in common is the attempt to look for the inner Filipino by examining indigenous languages (Mercado and Timbreza) or culture and values (Miranda, Alejo, and Gripaldo). However, because they are merely quasi-anthropological, the achievements of these authors, Abulad argues, fall short of what they promise. For Abulad, some of these authors are riddled with questions about method, such as, Mercado, Miranda, and Timbreza, whose works try too hard to adopt the social science (empirical) approach. For his part, Alejo is searching for the "Filipino loob" which Abulad identifies with the Greek notion of psyche or the Hegelian notion of Geist; therefore, Abulad wonders whether Alejo is simply repeating something that Western philosophers have been doing for a long time. Abulad's rather hasty lumping of loob, psyche, and Geist invites a second opinion and, I think, we must also contend. Meanwhile, while Abulad recognizes the effort of Gripaldo in defining what a Filipino philosopher should be, Abulad is simply not impressed by Gripaldo's apparent self-valorization. In contrast to Gripaldo, it is not surprising that

25 See Leonardo N. Mercado, Explorations in Filipino Philosophy (Manila: Logos Publications, 2009); Dionisio M. Miranda, Buting Pinoy: Probe Essays on Value as Filipino (Manila: Divine Word Publications, 1992); Albert E. Alejo, Tao pô! Tuloy! Isang Landas ng Pag-unawa sa Loob ng Tao (Quezon City: Ateneo de Manila University Office of Research and Publications, 1990); Rolando M. Gripaldo, The Making of a Filipino Philosopher and Other Essays (Mandaluyong City: National Book Store, 2009); Florentino T. Timbreza, Pilosopiyang Pilipino (Manila: Rex Book Store, 1982); Florentino T. Timbreza, Intelektwalisasyon ng Pilosoiyang Filipino (Manila: De La Salle University Press, Inc., 1999); and Emerita S. Quito, A Life of Philosophy: Festschrift in honor of Emerita S. Quito (Manila: De La Salle University Press, 1990).

(C) 2019 Paolo A. Bolaños

https://www.kritike.org/journal/issue 25/bolanos december2019.pdf

ISSN 1908-7330

(cc) BY-NC-ND 
Abulad accepts Quito's position that philosophy cannot be defined ultimately, that we should have an "open-minded" approach in doing philosophy, as this is the only way that Filipino philosophy can progress. As such, Abulad does not deny the fact that Filipino philosophy exists, but it exists in multifarious ways and not just the anthropological way. But by saying this, Abulad seems to be intimating, especially towards the end of the essay, that, the survival of Filipino philosophy relies on the survival of philosophy itself, as it struggles to find its way between the two cultures that C.P. Snow spoke about.

The essay "Filipino Postmodernity: Quo Vadis?," in classic Abuladian fashion, brings two seemingly unrelated ideas together: "Filipino" and "postmodernity." Abulad makes no qualms, at the beginning, in declaring that, "the Filipino ... has already 'crossed the border' and has learned to accept the fact of what Martin Heidegger calls 'the second beginning' - what here we refer to as postmodernity." The second beginning, that Heidegger speaks about, results from a paradigm shift that occurred in the history of thought. Once again, this essay demonstrates Abulad's intellectual generosity by narrating his peculiar story of the history of philosophy or, more precisely, the history of postmodernity. Either way, Abulad seems to be suggesting that this history has a bearing on the development of Filipino philosophy - the becoming-philosophy, as it were, of Filipino thinking. The essay seems to offer, at least, three senses of the term "postmodernity." Firstly, "postmodernity" is "the paradigm shift," that is, it is the irreversible moment that Heidegger refers to as the "second beginning," whereas the "first beginning" was the invention of "thoeria" which occurred in ancient Greece. The second beginning occurred in the time of Descartes and Kant, "a period of merciless critique, aimed paradoxically at certitude, which resulted in the collapse of all Western and Eurocentric thinking." This crucial moment in human history, Abulad notes following Heidegger, is the "crisis of philosophy" that led to the postmodern shift. In this context, Kant completes the project of Descartes, as the former "has left nothing standing ... All knowledge is merely a phenomenon." Secondly, "postmodernity," Abulad declares, is the "end of Western domination," and, hence, paves the way for a new beginning which is "an equalizer of cultures, both East and West." In this context, then, postmodernity is actually the "third beginning": "... we beg the indulgence of the great Martin Heidegger and correct him somehow, giving to the East the honor of the first beginning, to Greece the second beginning and to the postmodern synthesis of both East and West the third beginning." Postmodernity, in this context, is the synthesis of apparent opposites, resulting in inclusivity, interconnectivity, dialogue, borderlessness, linkage, etc. Thirdly, "postmodernity" is always "a new beginning," Abulad claims. If it is always a new beginning, then 
postmodernity is not just the shift of no return initiated by Descartes and Kant, but, rather, postmodernity is a global attitude that is confined neither to a nationality nor a geographical location. Abulad's essay is, nevertheless, radically paradoxical in a couple of ways. On the one hand, while he cites "Jean-Francois Lyotard's assessment of postmodernity as a rejection of metanarratives," Abulad's history of philosophy/postmodernity is, essentially, itself a metanarrative. Perhaps, the only way to battle metanarratives is to come up with one's own metanarrative. On the other hand, the expatiation on "Filipino postmodernity" is done against the backdrop of the rise of President Rodrigo Duterte which, for Abulad, marks a crucial point in Philippine history, wherein "the concepts of good and bad might have transvalued themselves and what used to be the moral table of the 'civil society' has already turned stale and outdated. The times, I think, demand that we keep our minds open and dare to rethink and review our revered values." He does not, however, refer to Duterte as the postmodern President, but, perhaps, we live in a period that calls for a postmodern response that, hopefully, leads to our new beginning. I know that Abulad would not mind if we disagree with him on this point; as a matter of fact, disagreement, is, for him, the essence of the postmodern attitude. Whether he is right or wrong about this rather ticklish subject, we will only find out when our history has matured, as "the owl of Minerva begins its flight only with the onset of dusk," 26 to borrow from Hegel.

One brilliant student of mine perfectly describes what I termed earlier as Abulad's intellectual generosity: “... his ability to drive a point coming from a plethora of perspectives; regardless of how these ideas are tied up in the end ... this is something that we hardly see in today's age of academic specialization." ${ }^{27}$ Moreover, I especially appreciate my student's personal impression of Abulad's legacy: “... a man of education, ein gebildeter Mensch .... Br. Romy's greatest legacy is this, philosophy as a 'general' education in the fullest sense of the term." 28

In addition to Abulad's new essays we include in this section "Abulad's Postmodern Eyes," an intimate tribute written by Fleurdeliz AltezAlbela. In this short piece, Altez-Albela paints a portrait of Abulad as an educator and icon of academic philosophy in the Philippines. Abulad's take on postmodernity is presented as a critical attitude against the backdrop of the contemporary human situation, as opposed to a historically-specific philosophical system. The following characteristics of Abulad's brand of

\footnotetext{
${ }^{26}$ G.W.F. Hegel, Preface to Elements of the Philosophy of Right, trans. by H.B. Nisbet (Cambridge: Cambridge University Press, 1991), 23.

27 Ranier Abengaña, "Two Papers by Br. Romy," in an email message to the Editorial Board of Kritike (December 2019).

${ }^{28} \mathrm{Ibid}$.

(c) 2019 Paolo A. Bolaños

https://www.kritike.org/journal/issue 25/bolanos december2019.pdf

ISSN 1908-7330
}

(cc) BY-NC-ND 
postmodernism are outlined: via negativa as a way of thinking, a paradigm shift motivated by the refusal to accept metanarratives, dialogical philosophy, intersubjective-thereby, ethical. Ultimately, this paper underscores Abulad's radical critique of the present-a revaluation, of sorts, of the contemporary role of philosophy. Moreover, it is a testimony to Abulad's pedagogy of postmodernity - that is to say, of how he teaches his students to think with postmodern eyes: an openness to the "otherwise than said" that is a profound gesture of hospitality and, yet, a relentless critique.

I wish to take advantage of the remaining space of this introduction to briefly expressed my gesture of thanks to Br. Romy (as we all called him) by sharing a snippet of memory.

I have merely overheard conversations about who Romualdo Abulad was when I was in college. My professors, who are contemporaries of Abulad (Alfredo Co, Josephine Pasricha, Magdalena Villaba), mentioned his name in passing. "He is among the best that the University of Santo Tomas has ever produced," they said. And so, I was intrigued. By the time I met Abulad, some 20 years ago, he was already in his 50s and I was a naïve twenty-two-yearold graduate student who was struggling to read the works of Friedrich Nietzsche. The first time I heard him speak was in the $1^{\text {st }}$ Thomasian Philosophers Reunion Convention, held at the University of Santo Tomas in 2000, where he delivered his influential "What is Postmodernism?" I listened to Abulad's lecture intently and, immediately, I was impressed by the way he wrote and read his paper, the tempo of which resembled a military cadence which made his delivery even more riveting. In that paper, he argued that Nietzsche is the father of postmodernism, something entirely new to me at that time. Right there and then, I knew whom I was going to pursue as my thesis adviser. The following year, Abulad was invited to teach a course on Kant at the Graduate School of the University of Santo Tomas. I enrolled in his class with the intention of asking him to become my thesis adviser; secondarily only, I was curious why Kant was such a big deal. Well, no regrets! If I could competently discuss Kant today, it is because I enrolled, willy-nilly, in that graduate course on Kant that Abulad taught. Asking him to become my thesis adviser did not come as easily as I thought. He actually rejected the first research proposal I submitted to him and told me to get back to him when I was ready with something acceptable. Yes, Abulad was an exacting thesis adviser, especially when he was younger. It took me another year to write a new proposal on Nietzsche's philosophical anthropology. When he finally agreed to take me under his wing, it was the beginning of our long philosophical relationship which eventually naturally evolved into a profound friendship, and then, beyond our professional relationship, he treated me like a son. I am sure that the same affection from him was felt by many.

(C) 2019 Paolo A. Bolaños

https://www.kritike.org/journal/issue 25/bolanos december2019.pdf

ISSN 1908-7330

(cc) BY-NC-ND 


\section{ABULAD, PHILOSOPHY, AND INTELLECTUAL GENEROSITY}

There was never a dull moment with Br. Romy. Indeed, every conversation we had were philosophical-over books or theses, food, coffee, and, of course, beer! Albeit philosophical, our conversations were neither strained nor anxious. I will remember Abulad as a radical thinker, despite his unassuming demeanor and the vocation he embraced. To me, while he was not an angel, he did remind me of how I imagine the figure of the historical Christ. Yes, more like a postmodern Christ who pays attention to you generously.

Maraming salamat po, Br. Romy. Ruhe in Frieden.

Department of Philosophy, University of Santo Tomas, Philippines

\section{References}

Abulad, Romualdo E., "A Philosopher's View from EDSA," Karunugan, 18 (2001), 11-14.

, "Ang Diwa at Kaisipan ng Pilipino sa Kasaysayan ng Himagsikan," Malay, 5:5 (June-December 1986), 37-48.

"Ang Pilosopiya ng Salapi ni Georg Simmel," Karunungan, 6 (1989), 1-15.

"Atheism as a Prophetic Voice in the Era of Paradigm Shift," Diwa: Studies in Philosophy and Theology, 38:2 (November 2013), 77-90. "Can Science Save the World?," Sophia, 5:3 (February-May 1976). "Confucianism and Filipino Culture," Scientia, 5:2 (December

2016), $\quad 1-16, \quad<$ http://scientia-sanbeda.org/wpcontent/uploads/2017/05/vol-5.2-r-abulad.pdf $>$. "Contemporary Filipino Philosophy," Karunungan, 5 (1988), 1-13.

"Criticism and Eternal Peace: Kant's Critique of Pure Reason as the Method of Scientific Metaphysics" (Postdoctoral Research, University of Hamburg, 1980).

"Doing Philosophy in the Philippines: Towards a More Responsive Philosophy for the 21st Century," Suri, 5:1 (2016), 1-20, $<$ https://suri.pap73.org/issue6/Abulad SURI 2016.pdf $>$.

"Ethics and Governance in the Postmodern Glocalized Society," USC Graduate Journal, 28:2 (March 2012), 161-183.

"Ethics, Indigenous Ethics, and the Contemporary Challenge: Attempt at a Report on Ethics for the Filipino Today," Scientia, 8:1 (March 2019), 1-20, <http://scientia-sanbeda.org/wpcontent/uploads/2019/03/1Abulad.pdf $>$.

"Facing the Moral Challenge of the Post-Modern Times," Karunungan, 16 (1999), 1-3. 
"Filipino Philosophy in Dialogue with Plato," Karunugan, 7 (1990), 1-13.

"Filipino Philosophy in the Turbulent Period of Postmodern Transition," USC Graduate Journal, 22:1 (October 2005), 148-165.

"Freedom and Responsibility: The Millenials' Quest for and Integration of the Good," Diwa: Studies in Philosophy and Theology, 43:1 (May 2019), 3-34.

"Fundamental Assumptions of Postmodernity," Karunungan, 21 (2004), 83-120.

"God and Postmodernity," Karunungan, 19 (2002), 5-13.

"Heidegger and the Pursuit of Being," Sophia, 1971-1981: The Best of A Decade (1981), 39-56.

"Immanuel Kant as a Pioneer of Postmodernity," The Thomasian Philosopher, 26 (2005), 120-128.

, "Kant and Postmodernism," PHAVISMINDA Journal, 2 (May 1998), 32-51.

, "Kant and the Filipino Quest for a Philosophy," Sophia, 11:1 (May-Aug 1981), 34-49.

"Kant and the Task of Contemporary Filipino Philosophy," Sophia, 16:1 (May-August 1986), 45-68.

“'Kant for Filipinos," Sophia,16:2 (September-December 1986), 3756.

"Kant's Critique of Pure Reason: A Science, a Discipline and a Consciousness," Sophia, 2:1 (September 1972), 29-45.

"Kant's Metaphysics," Sophia, 4 (April 1974).

"Kant's Philosophy of Man," Sophia, 20:1 (May-August 1990), 32-

46.

"Kant's View of Science," Sophia, 17:1 (August 1987), 8-18.

"Links Between East and West in the Philosophies of Shankara and Kant" (Ph.D. Dissertation, University of Santo Tomas, 1978).

"Martial Law and Religion," Scientia, 6:2 (December 2017), 45-59,

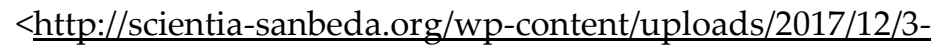
abulad.pdf $>$.

"Martin Heidegger: Mula Penomenolohiya Hanggang Eksistensiyalismo Hanggang Hermeneutika," Malay, 8: 1-2 (19891990), 47-64.

"Options for a Filipino Philosophy," Karunungan, 1 (1984), 17-30. “Origen's Contra Celsum: A Touch of Postmodernism," Diwa: Studies in Philosophy and Theology, 22:1 (May 1997), 26-40.

"Paradigm Shifts and Some Postmodern Prospects: Toward a Postmodern Filipino Philosophy," USC Graduate Journal, 26:2 (October 2009), 167-176. 


\section{ABULAD, PHILOSOPHY, AND INTELLECTUAL GENEROSITY}

"Philosophy and Politics: Do They Mix?," PHAVISMINDA Journal, 8 (May 2009), 1-18.

"Philosophy, Life, History," FEU Arts and Sciences Review, 4 (2001), 20-35.

"Pilipino sa Pilosopiya," Dialogue, 12:1 (August 1976), 159-168.

"Post-Machiavelli," Karunungan, 18 (2001), 91-100.

, "Postmodern Critique and the Ethics of Postmodernism," Karunungan, 19 (2002), 65-80.

"Projective Morality: An Ethics for a New Society," Sophia, 2:2 (November 1972), 94-99.

"Prophetic Dialogue Across Civilizations," Karunugan, 25

(September 2008), 23-26.

"Rationale for a Filipino Philosophy," Sophia, 12:1 (May-August 1982), 1-16.

, "Revolution Through Values," Sinag, 1:1 (October 1989), 25-37.

" "Rousseau and Kant," Sophia, 2:3 (January 1973), 130-133.

"Shankara and Kant: A Comparison," Sophia, 14:2 (September-

December 1984), 73-97.

, "Si Kant at ang Pilosopiya sa Pilipinas," Malay, 1:1 (September 1981), 57-68.

"St. Thomas Aquinas and Postmodernism," Karunungan, 22 (2005), 53-61.

"The Future of Ethics: A Postmodern View," Diwa: Studies in Philosophy and Theology, 27:1 (May 2002), 14-31.

"The Materialist Prospect," Sophia, 4:3 (February-May 1975).

"The Meaning of Postmodernism," Talad, 4:2 (July 2004), 138-149;

"The Mystical Philosophy of St. John of the Cross," Karunungan, 9 (1992), 40-58.

"The Philosophical Bases of Values Education," The DLSU

Graduate Journal, 12:2 (1987), 145-158.

"The Relevance of Critical thinking in Contemporary Philippine

Society," Scientia, 6:1 (June 2017), 34-66, < $\underline{\text { http://scientia- }}$ sanbeda.org/wp-content/uploads/2017/06/2-R-E-Abulad.pdf $>$.

"The Role of Philosophy in the Technological Age," Karunungan,

21 (2004), 170-184.

, "The Significance of Kong $\mathrm{Zi}$ in the Age of Postmodernism," Karunugan, 20 (2003), 1-21.

"The Status of Metaphysics in Kant's Critique of Pure Reason"

(Master's Thesis, Ateneo de Manila University, 1975).

"Three Problems in Kant's Philosophy," Sophia, 11:3 (January-

April 1982), 158-167.

"Toward a Philosophy of Science," Sophia, 3:3 (January 1974).

(c) 2019 Paolo A. Bolaños

https://www.kritike.org/journal/issue 25/bolanos december2019.pdf

ISSN 1908-7330

(c) BY-NC-ND 
"Toward a Reconstruction of Christology in the Context of Postmodernity" (Master's Thesis, Divine Word Seminary, 2003). "What is Postmodernism?," Karunungan, 17 (2000), 34-54. "Why President Duterte Could be Correct," in King's Clarion (Christ the King Seminary, Quezon City: June 2016-2017).

Abulad, Romualdo E., and Alfredo P. Co, Two Filipino Thomasian Philosophers on Postmodernism, ed. by Romualdo E. Abulad (Manila: University of Santo Tomas Publishing House, 2004).

Abulad, Romualdo E., and Emmanuel C. de Leon, "An Interview with Romualdo Abulad, SVD," Kritike: An Online Journal of Philosophy, 10:1 (June 2016).

Alejo, Albert E., Tao pô! Tuloy! Isang Landas ng Pag-unawa sa Loob ng Tao (Quezon City: Ateneo de Manila University Office of Research and Publications, 1990).

Co, Alfredo P., "In the Beginning ... A Petit Personal Historical Narrative of the Beginning of Philosophy in the Philippines," in Across the Philosophical Silkroad: A Festschrift in Honor of Alfredo P. Co, Vol. VI (Manila: University of Santo Tomas Publishing House, 2009).

Festin, Raymun J., “Duterte, Kant, and Philosophy,” PHAVISMINDA Journal, 16-17 (May 2018), 16-96.

Gripaldo, Rolando M., The Making of a Filipino Philosopher and Other Essays (Mandaluyong City: National Book Store, 2009).

Hegel, G.W.F., Elements of the Philosophy of Right, trans. by H.B. Nisbet (Cambridge: Cambridge University Press, 1991).

Mercado, Leonardo N., Explorations in Filipino Philosophy (Manila: Logos Publications, 2009).

Miranda, Dionisio M., Buting Pinoy: Probe Essays on Value as Filipino (Manila: Divine Word Publications, 1992).

Quito, Emerita S., A Life of Philosophy: Festschrift in honor of Emerita S. Quito (Manila: De La Salle University Press, 1990).

Timbreza, Florentino T., Intelektwalisasyon ng Pilosoiyang Filipino (Manila: De La Salle University Press, Inc., 1999). Pilosopiyang Pilipino (Manila: Rex Book Store, 1982). 